\title{
Tüketicilerin organik gıdalar hakkında bakış açılarının değerlendirilmesi
}

\author{
Sibel ÖZKAN ${ }^{\mathrm{a}}$, Zuhal Aydan SAĞLAM ${ }^{\mathrm{b}}$
}

\section{ÖZET}

Amaç: Bu çalışma bireylerin organik gıdalara karşı bilgi, bilinç düzeylerini değerlendirip; tüketiciye organik gıda seçimi ve tercihi konusunda yeni bir bakış açısı kazandırmayı amaçlamaktadır. Yöntem: Araştırma Şubat-Mayıs 2019 tarihleri arasında İstanbul ili Kadıköy ilçesi Kozyatağı, Erenköy, Caddebostan, Fikirtepe, Göztepe ve Koşuyolu semtlerinde halk pazarları ve marketlere gelen 18 yaş ve üzeri toplam 370 yetişkin erkek ve kadın bireyin organik gıdalara karşı bakış açılarını değerlendirmek amacı ile gerçekleştirilmiş̧tir. Katılımcılara araştırmacı tarafindan anket uygulanmıştır. Bulgular: Çalışmada kadın ve erkek bireylerin \%84 ü şimdiye kadar organik gıda satın almıştır. Ek olarak bireylerin \% 89.3'ü organik gıdayı sağlıklı olduğu için tercih ettiklerini belirmiştir. Ancak bireylerin \%95 i organik tarım logosu ve organik gıda hakkında yeterli bilgiye sahip olmadıkları tespit edilmiştir. Araştırmada kişilerin organik gıdaların sağlığa olumlu etkilerinin olduğunu düşünme durumları ile eğitim durumları arasında anlamlı bir farklılık vardır. Her eğitim seviyesindeki katılımcı, organik gıdanın sağlığa etkisinin olumlu olduğunu büyük oranda düşünmektedirler. Ancak organik gıda tanımı ile bireylerin eğitim seviyesi arasında anlamlı bir ilişki yoktur. Sonuç: Tüketicilerin organik gidalara bakış açıları değerlendirilirken bireylerin daha fazla bilgilendirilmeye ve yönlendirilmeye ihtiyacı vardır. Doğru bilgilendirme ve yönlendirme ile organik tarım güçlenecektir. Bunlara ek olarak doğa ve insan sağlığı korunacak, gelecek nesillere iyi bir dünya birakılabilecektir.

Anahtar Kelimeler: Alışkanlık, organik gıda, sağlık, tutum, tüketici davranışı

\section{Evaluation of the considerators' view of organic foods}

\begin{abstract}
Objective: This study aims to consider the level of knowledge and awareness of individuals about organic foods and give the consumer a new perspective on organic food selection and preference. Methods: The research was carried out between February-May, 2019 in order to evaluate the views of 370 male and female adults who are aged 18 and over and came to the public markets and markets in Kadıköy, Erenköy, Caddebostan, Fikirtepe, Göztepe and Koşuyolu districts of Istanbul. A questionnaire was applied to the participants by the researcher. Results: The results show that, $84 \%$ of male and female individuals have purchased organic food so far. In addition, $89.3 \%$ of individuals stated that they prefer organic foods because they are healthy. However, it was determined that $95 \%$ of the individuals do not have sufficient information about the organic agriculture logo and organic food. In the research, there is an important difference between the idea that organic foods have positive effects on health and education levels. Participants of all educational levels think that organic foods have a positive effect on health. However, there is no significant relationship between the definition of organic food and the education level of individuals. Conclusion: Individuals need more information and guidance when evaluating consumers' perspectives on organic foods. Organic farming will be strengthened with accurate and appropriate information and guidance. In addition, nature and human health will be protected and a good world will be left for future generations.
\end{abstract}

Key words: Attitude, organic food, health, habit, consumer behavior

\footnotetext{
Geliș Tarihi: 07.05.2020

Kabul Tarihi: 06.11.2020

aUlus Liv Hospital, İstanbul, Türkiye, e-posta: dytsibelozkan@gmail.com ORCID: 0000-0001-9403-636X

bSağlık Bilimleri Üniversitesi Tıp Fakültesi İstanbul Sağlık Uygulama Merkezi Aile Hekimliği, İstanbul, Türkiye, e-posta: zsaglam@hotmail.com ORCID: 0000-0003-2523-3495

Sorumlu Yazar/Correspondence: Sibel Özkan ｅ-posta: dytsibelozkan@gmail.com

Çalışma yüksek lisans tezinden türetilmiştir.

Atıf: Özkan S, Sağlam ZA. Tüketicilerin organik gıdalar hakkında bakış açılarının değerlendirilmesi. Sağlık ve Yaşam Bilimleri Dergisi2020;2(2):36-42.

Citation: Ozkan S, Saglam ZA. Evaluation of the considerators'view of organic foods. Journal of Health and Life Science2020;2(2):36-42.
} 


\section{GíRiş}

Günümüzün birçok gida üretim sistemi sürdürülememekle birlikte gelecekte gida üretme kabiliyetini de tehlikeye atmaktadır. ${ }^{1}$ Gün geçtikçe kentleşen bir gezegenin gida ve beslenme gereksinimlerine cevap verebilmek için daha fazla gıda üretimine ihtiyacımız vardır. İnsan nüfusunun artışı ile sanayileşme de gelişim göstermiştir. Hava ve su kirliliği, toprak erozyonu ve ormanların yok olması, küresel ısınma ve ozon tabakasının incelmesi sanayileşmenin olumsuz sonucu olarak günümüzde karşımıza çıkmaktadır. Bu risk ve tehlikelere karşı bir hareket olan çevreciliğin ilk adımları 19. yüzyıl sonunda Amerika da atılmıștır. ${ }^{2}$ Böylece 20. yüzyılın ikinci yarısında çevrecilik, çevre bilinci, doğaya saygı gibi akımların oluşması bireylerin tüketim davranışlarını etkiler hale gelmiştir. ${ }^{3}$ Yeni bir üretim sistemi olarak gelişen organik tarım sistemi ise bu akımların sonucunda ortaya çıkmıştır. ${ }^{4}$ Ekolojik tarımın çevre ile etkileşimi birçok olumlu etkileri de beraberinde getirmektedir. Toprağın verimliliği, çayır ve mera alanlarının korunması, su kaynaklarının korunması ve $\mathrm{CO}^{2}$ salınımının azalması gibi konuların önemini belirginleştirmektedir. Organik tarımın temel prensibi doğal çevreyi korumak ve gelecek nesillere daha iyi bir doğa bırakmaktır. Tüm bunlardan dolayı organik tarımın bireyler tarafından sağlığa olumlu katkıları ve sağlıklı gelecek nesiller için güven uyandırması nedeniyle tüketiciler için önem arz etmektedir. ${ }^{5}$ Organik tarım ve gıda hakkında birçok literatür çalışması mevcut. Daha önceki çalışmalarda konuya daha çok çevresel duyarlılığın değerlendirilmesi, organik ürün üreticileri ile ilgili veya organik gıdaların pazarlanması gibi araştırmalara yer verilmiştir. Bu çalışmada; Organik gıda tüketimi ile ilgili tüketicilerin organik gıda algısı, gıda seçimini etkileyen olumlu veya olumsuz etkenler, tüketicilerin organik gıda konusunda bilgi ve bilinç düzeyleri incelenerek konuya farklı bir bakış açısı getirilmesi amaçlanmaktadır.

Organik tarım, toprak-bitki-hayvan ve insan arasındaki dengeyi en tutarlı biçimde koruyan bir sistemdir. İnsana ve çevreye zarar vermeden yapılmaktadır. Doğal çevreyi ve doğal döngüyü bozmadan iyileştirmeyi hedefleyen bir sistemdir. Diğer bir deyişle belirli bir kontrol ve sertifikasyon işlemiyle, tarım dışı girdi ve pestisit gibi maddeler kullanılmadan gerçekleştirilen tarım yöntemi olarak ifade edilmektedir. ${ }^{6}$ Organik tarımın başlıca amacı doğal dengeyi korumaktır. Ekolojik tarımla ilgili tüm ulusal ve uluslararası standartlar, ürünün topraktan rafa gelene kadar her aşamasının kontrol edilip sertifikasyonunun olmasinı zorunlu tutmaktır. Sertifikasyon uygulamasının en temel amaci, ekolojik ürün tüketerek hem doğayı korumayı hedefleyen hem de sağlıklı yaşamayı tercih eden tüketicilere bir güvence sağlamaktır. Bu uygulamanın diğer bir yararı da üreticiye yönelik olmasıdır. Organik yetiştiricilik, sağlık ve çevresel olarak yürütülebilir tarımsal üretim sistemlerinin bütünleştiği ve amaçlandığı bir yaklaşımdır. Aynı zamanda toprakta yetişen canlılarla uyumlu ve bütünleşen bir sistemdir. Kitalara göre incelendiğinde; şu anda, dünya çapında 43.7 milyon hektar organik tarım yönetimi altındadır (verilerin çoğu 2014 yılı sonunda belgelendirilmiştir). ${ }^{7}$ Organik tarım alanlarının çoğunun bulunduğu bölge Okyanusya'dır. 17,3 milyon hektarla Okyanusya'nın ardindan Avrupa (11.6 milyon hektar), Latin Amerika (6.8 milyon hektar), Asya (3.6 milyon hektar), Kuzey Amerika (3.1 milyon hektar) ve Afrika (1.3 milyon hektar) ile hektar) gelmektedir. ${ }^{7}$ Okyanusya, küresel organik tarım arazisinin \%40'ına sahiptir. Daha sonra yıllar boyunca çok fazla organik toprak büyümesi olan bir bölge olan Avrupa, dünyanın organik tarım alanlarının dörtte birinden fazlasını kaplamaktadır. Avrupa' dan sonra ise organik tarım arazisinin neredeyse \%16'sını Latin Amerika takip etmektedir. 2011'den bu yana büyük bir organik toprak büyümesi yaşayan Avustralya, en iyi organik tarım arazisine sahip ülkedir; Tarım arazilerinin \%97'si geniş otlatma alanlarını kapsar. ${ }^{7}$ Avusturalya'dan sonra sirayı Arjantin ve Amerika izlemektedir. ${ }^{7}$ Ülkemiz ise organik tarıma en elverişli ülkelerden biri olduğu, iklim koşulları, kimyasal girdilerin az olması ve ürün çeşitliliğinin zengin olmasıyla kanıtlanmıştır. Yurtdışından gelen talepler doğrultusunda ülkemizde organik tarım ilk 1980'li yıllarda Ege Bölgesinde başlanmıştır. 1991 yılından sonra Avrupa Birliğinin yönetmeliği doğrultusunda devam etmiştir. ${ }^{8}$ Türkiye'de yeni ve moda olan beslenme şekillerinin de etkisiyle, çevreye ve insan sağlığına verilen önem artmış olup, tüketiciler özellikle sağlık ve beslenme alanında bilinçlendirilmeye çalışılmıştır. Bu doğrultuda da "organik" adı verilen gida grubuna talebin gün geçtikçe arttığı görülmektedir. Organik gıda pazarı, özellikle Avrupa Birliği'nde, dünya genelinde gelişmiş ekonomilerde en hızlı büyüyen sektörlerden biri haline gelmiştir." Organik gıda 'sentetik gübreler ve kimyasallar eklenmeden üretilmiş, depolanmış ve işlenmiş gıda garantisi" olarak tanımlanmıştır. ${ }^{10}$ Ek olarak, Chinnici ve ark. (2002), organik ürünleri, çevre dostu bir işlemle yetiştirilen gıda olarak tanımlamıştır. ${ }^{11}$ Ayrıca, ABD Tarım Bakanlığı Ulusal Organik Standartlar Kurulu (USDA, 2008) '"organik', terimi için ulusal bir standart oluşturmuştur. ${ }^{12}$

Doğal gıdalar, katkı ve koruyucu madde içermez; fakat genetiği değiştirilmiş içerikler ihtiva edebilir. Başka bir deyişle, içindekiler etiketleri benzer olsa da bu ürünler organik şekilde üretilmemiş yani organik gıdalarla aynı kriterlere göre düzenlenmemiştir. ${ }^{13}$ Doğal ürün, yapay bileşen, katkı maddesi içermeyen 
fakat organik yerine geleneksel bileşenlerden oluşabilir. Doğal ürünlerin etiketlenmesi söz konusu olmayıp, aynı zamanda devlet tarafindan kontrol edilen "doğal" etiketi de yoktur. ${ }^{14}$

Yeşil yiyecekler iki gruba ayrılabilir. İlk grup yeşil gıdalardır. Yeşil gıdalar güvenli, kaliteli, besleyici, tüketiciler için sağlıklı ve sürdürülebilir kalkınma ilkesi altında üretilen hayvan refahı ile ilgilenen gıdalara atıfta bulunur. ${ }^{15}$ Ayrıca yeşil gıdalar organik olarak yetiştirilen, geri dönüştürülebilen veya tekrar kullanılabilen, doğal içerik veya geri dönüşüm içeriği ile çevreyi kirletmemeyi ve hayvan refahını korumayı esas alan gıda anlamına da gelir. ${ }^{16,17}$ İkinci grup organik gidalara atıfta bulunur. Organik gidalar, sentetik olarak üretilen kimyasallar veya gübreler, herbisitler, pestisitler, mantar öldürücüler, jenerik modifikasyonlar kullanılmadan üretilen ve depolanan ve/veya işlenen yiyecekler anlamına gelir. ${ }^{18}$ Tüm yeşil yiyecekler organik yiyecek değildir. Yeşil gıda logosuyla satılmasına izin verilen g1dalar güvenli ve besleyicidir, organik gidalar ise en katı sertifikasyondur. ${ }^{19}$ Organik gıdalar ile yeşil gıdaların ortak özellikleri gıda güvenliğini sağlamak, sağlık sorunlarını en aza indirmek, çevre ve hayvan refahını korumaktır. ${ }^{20}$ Ek olarak Organik gidalar, geleneksel gıdalardan daha sağlıklı, daha güvenli, daha lezzetli ve daha kaliteli olarak kabul edilir. ${ }^{21-23}$

\section{YÖNTEM}

Bu çalışma Şubat-Mayıs 2019 tarihleri arasında İstanbul ili Kadıköy ilçesi Kozyatağı, Erenköy, Caddebostan, Fikirtepe, Göztepe ve Koşuyolu semtlerinde halk pazarları ve marketlere gelen 18 yaş ve üzeri toplam 370 yetişkin erkek ve kadın bireyin organik gıdalara karşı bakış açılarını değerlendirmek amacı ile gerçekleştirilmiştir. Araştırma, kesitsel ve analitik bir çalışma olarak planlanmıştır. $\mathrm{Bu}$ doğrultuda; Araştırmanın Evren ve Örneklemi:

Basit Rastgele Örneklemede Örneklem Genişliği Tahmini

$$
\mathrm{n}=\frac{\mathrm{Nt}^{2} \mathrm{pq}}{\mathrm{d}^{2}(\mathrm{~N}-1)+\mathrm{t}^{2} \mathrm{pq}}
$$

$\mathrm{N}$ : Evrendeki birey sayısı

n: Örnekleme alınacak birey sayısı

p: İncelenen olayın görülüş sıklığ1

q: İncelenen olayın görülmeyiş sıklığ

t: Belirli serbestlik derecesinde ve saptanan yanılma düzeyinde $t$ tablosundan bulunan teorik değer

d: Olayın görülüş sıklığına göre yapılmak istenen \pm sapma

$$
\mathrm{n}=\frac{(10000)(1.96)^{2}(0.5)(0.5)}{(0.05)^{2}(10000-1)+(1.96)^{2}(0.5)(0.5)}
$$

Çalışma evreninden basit tesadüfi örnekleme yöntemi ile örneklem genişliği hesaplaması yapıldığında, 10000 kişi evren kabul edildiğinde gerekli değerler formülde yerine konulduğunda toplanması gereken minimum kişi sayısı 370 olarak hesaplanmıştır. Burada n'in seçimi önsel olarak hiçbir bilginin olmadığı durum için seçilmiştir. Çünkü, p. q değerini maksimum yapan değerdir (Yamane, 2010;118). p. q değeri arttıkça formülde bulunan değeri de büyüyeceğinden, örneklem boyutunun en büyük çıkabilmesi için herhangi bir önsel bilginin olmadığı durumda olarak kabul edilir. ${ }^{24}$

Araştırmaya başlamadan önce İstanbul Bilgi Üniversitesi Etik Kurulu'nun 12.02.2019 tarihli, 2019-20016-26 nolu kararı ile 'Etik Kurul Onayı', alınmıştır. Her hasta yakınından gönüllü onam alınarak çalışma gerçekleştirilmiştir.

Çalışmada istatistiksel programlardan olan IBM SPSS statistics 25.0 paket programı kullanılmıştır. Veriler, yüzde, aritmetik ortalama, standart sapma, minimum, maksimum gibi tanımlayıcı istatistiklerin yanısıra kategorik iki grubun karşılaştırılmasında kikare testi kullanılmıştır. ${ }^{25}$

\section{BULGULAR}

Araştırmaya katılan kişilerin 225'i (\%60.8) kadın bireylerden, 145'i (\%39.2) erkek bireylerden oluşmaktadır. \%32.4' ü ise 25-34 yaş aralığında olup diğer yaş gruplarına göre çalışmaya en çok katılım sağlayan bireylerdir (\%9.7'si en az katılım sağlayan, 55 yaş ve üzeri bireylerdir). Okuryazarlık düzeyleri değerlendirildiğinde, katılımcıların \%46.5'inin lisans seviyesinde olduğu bulunmuştur. Ek olarak bireylerin \%9.5'inin ise okuryazar olmadığı tespit edilmiştir. Katılımcıların; medeni durumları değerlendirildiğinde ise $\% 49.5$ 'i evlidir. Mesleğe göre değerlendirildiğinde bireylerin en çok özel sektörde görev yaptıkları sonucu ortaya çıkmıştır (\%26.5). Özel sektörden sonra siralamayı hizmet sektörü (\%22.4) ve çalışmayan bireyler (\%22.4) almaktadır. Katılımcıların \%46.8'i çocuk sahibi değildir. Son olarak bireylerin; \%8.6's1 1600 ile 1999 gelire sahipken, \%40’1 5000 TL ile üzeri aylık gelire sahiptir.

Araştırmada bireylerin \%88.8'i organik gıdaların sağlığa olumlu etkisinin olduğu belirtmiştir (Tablo $1)$. 
Tablo 1. Bireylerin "organik gıdaların sağlığa olumlu etkisi" üzerine merak edilen soruya verdikleri cevabın dağılımı

\begin{tabular}{|c|c|c|c|}
\hline & & $\mathrm{n}$ & $\%$ \\
\hline \multirow{3}{*}{$\begin{array}{l}\text { Organik } \\
\text { g1daların } \\
\text { sağlığa } \\
\text { olumlu etkisi }\end{array}$} & Evet & 159 & 88.8 \\
\hline & Hayır & 1 & 0.6 \\
\hline & Emin değilim & 19 & 10.6 \\
\hline
\end{tabular}

Araştırmaya katılanların organik olmayan gıdayı hangisi en iyi tanımlar sorusuna yaklaşımları yaş bazında incelendiğinde; 25 ile 34 yaş arası katılımcıların \%39.2’ si genetiği değiştirilmiş ürün ve kimyasal katkı maddesi olan ürün olarak tanımlamış, 35 ile 44 yaş arası katılımcıların \%35.1'i ise serada yetiștirilmiş ürün olarak tanımlamıștır (Tablo 2).

Tablo 2. Yaşa göre "Organik Gıda” hakkında yeterli bilgiye sahip olmayan katılımcıların cevap dağılımları

\begin{tabular}{|c|c|c|c|c|c|c|c|c|c|c|}
\hline & \multicolumn{2}{|c|}{25 yaş altı } & \multicolumn{2}{|c|}{$25-34$ aras1 } & \multicolumn{2}{|c|}{$35-44$ aras1 } & \multicolumn{2}{|c|}{$45-54$ aras 1} & \multicolumn{2}{|c|}{$\begin{array}{l}55 \text { yaş } \\
\text { üzeri }\end{array}$} \\
\hline & $\mathrm{n}$ & $\%$ & $\mathrm{n}$ & $\%$ & $\mathrm{n}$ & $\%$ & $\mathrm{n}$ & $\%$ & $\mathrm{n}$ & $\%$ \\
\hline \multicolumn{11}{|c|}{ Size göre organik olmayan gıdanın tanımını aşağıdakilerden hangisi iyi bir şekilde betimleyebilir? } \\
\hline $\begin{array}{l}\text { Genetik olarak } \\
\text { değiştirilmiş ürün }\end{array}$ & 22 & 18.3 & 47 & 39.2 & 31 & 25.8 & 15 & 12.5 & 5 & 4.2 \\
\hline Serada yetiştirilen ürün & 4 & 5.4 & 19 & 25.7 & 26 & 35.1 & 18 & 24.3 & 7 & 9.5 \\
\hline İşlenmiş ürün & 15 & 14.0 & 36 & 33.6 & 32 & 29.9 & 13 & 12.1 & 11 & 10.3 \\
\hline $\begin{array}{l}\text { Kimyasal katkı } \\
\text { maddesi olan ürün }\end{array}$ & 20 & 16.5 & 43 & 35.5 & 34 & 28.1 & 16 & 13.2 & 8 & 6.6 \\
\hline
\end{tabular}

Tablo 3. Okuryazarlık durumuna göre “Organik Gıda” hakkında yeterli bilgiye sahip olan katılımcıların cevap dağılımları

\begin{tabular}{|c|c|c|c|c|c|c|c|c|c|c|}
\hline & \multicolumn{2}{|c|}{$\begin{array}{l}\text { Okuryazar } \\
\text { /Okuryazar değil }\end{array}$} & \multicolumn{2}{|c|}{ İlkokul } & \multicolumn{2}{|c|}{ Ortaokul } & \multicolumn{2}{|l|}{ Lise } & \multicolumn{2}{|c|}{$\begin{array}{l}\text { Lisans } \\
\text { ve/veya } \\
\text { üzeri }\end{array}$} \\
\hline & $\mathrm{n}$ & $\%$ & $\mathrm{n}$ & $\%$ & $\mathrm{n}$ & $\%$ & $\mathrm{n}$ & $\%$ & $\mathrm{n}$ & $\%$ \\
\hline \multicolumn{11}{|c|}{ Organik gıdanın tanımını aşağıdakilerden hangisi iyi bir şekilde betimleyebilir? } \\
\hline Doğal ürün & 12 & 8.2 & 48 & 32.7 & 39 & 26.5 & 27 & 18.4 & 21 & 14.3 \\
\hline İşlenmemiş ürün & 9 & 8.6 & 32 & 30.5 & 31 & 29.5 & 22 & 21.0 & 11 & 10.5 \\
\hline $\begin{array}{l}\text { Hormonsuz yetişmiş } \\
\text { ürün }\end{array}$ & 17 & 12.8 & 42 & 31.6 & 33 & 24.8 & 27 & 20.3 & 14 & 10.5 \\
\hline Çevre dostu ürün & 6 & 8.7 & 22 & 31.9 & 15 & 21.7 & 20 & 29.0 & 6 & 8.7 \\
\hline $\begin{array}{l}\text { Tarım bakanlı̆ğ } \\
\text { sertifikalı ürün }\end{array}$ & 2 & 4.1 & 12 & 24.5 & 18 & 36.7 & 12 & 24.5 & 5 & 10.2 \\
\hline Sağlıklı gıda ürünü & 10 & 10.9 & 27 & 29.3 & 28 & 30.4 & 17 & 18.5 & 10 & 10.9 \\
\hline Diğer & 0 & .0 & 2 & 50.0 & 0 & .0 & 1 & 25.0 & 1 & 25.0 \\
\hline \multicolumn{11}{|c|}{ Organik gıdalar hakkında merak ettiğiniz bilgileri nereden öğreniyorsunuz? } \\
\hline İnternet & 1 & 1.0 & 8 & 7.6 & 6 & 5.7 & 18 & 17.1 & 72 & 68.6 \\
\hline Televizyon & 8 & 10.3 & 14 & 17.9 & 12 & 15.4 & 14 & 17.9 & 30 & 38.5 \\
\hline Dergi/Gazete & 0 & .0 & 4 & 8.9 & 7 & 15.6 & 12 & 26.7 & 22 & 48.9 \\
\hline Çevre duyumları & 15 & 13.8 & 23 & 21.1 & 20 & 18.3 & 11 & 10.1 & 40 & 36.7 \\
\hline Satış elemanları & 4 & 25.0 & 1 & 6.3 & 0 & .0 & 1 & 6.3 & 10 & 62.5 \\
\hline Diğer & 0 & .0 & 11 & 35.5 & 5 & 16.1 & 1 & 3.2 & 14 & 45.2 \\
\hline \multicolumn{11}{|c|}{ Organik gıdaları neden tüketiyorsunuz? } \\
\hline Kalitesine güveniyorum & 7 & 7.1 & 12 & 12.2 & 7 & 7.1 & 18 & 18.4 & 54 & 55.1 \\
\hline Tadı ve lezzeti çok iyi & 8 & 7.4 & 24 & 22.2 & 19 & 17.6 & 13 & 12.0 & 44 & 40.7 \\
\hline Fiyatı uygun & 3 & 11.1 & 12 & 44.4 & 9 & 33.3 & 1 & 3.7 & 2 & 7.4 \\
\hline Besin değeri yüksek & 10 & 7.8 & 22 & 17.1 & 18 & 14.0 & 17 & 13.2 & 62 & 48.1 \\
\hline Doğal yaşama katkısı var & 13 & 11.1 & 25 & 21.4 & 18 & 15.4 & 14 & 12.0 & 47 & 40.2 \\
\hline \multicolumn{11}{|c|}{ Organik gıdaları satın alırken en çok hangi çeşit ürün/ürünleri tercih ediyorsunuz? } \\
\hline Tahıl ürünleri & 12 & 11.7 & 22 & 21.4 & 15 & 14.6 & 11 & 10.7 & 43 & 41.7 \\
\hline Sebze- Meyve ürünleri & 13 & 9.1 & 26 & 18.2 & 19 & 13.3 & 18 & 12.6 & 67 & 46.9 \\
\hline Süt ürünleri & 11 & 10.4 & 16 & 15.1 & 8 & 7.5 & 15 & 14.2 & 56 & 52.8 \\
\hline Et ürünleri & 1 & 1.4 & 15 & 21.4 & 6 & 8.6 & 12 & 17.1 & 36 & 51.4 \\
\hline
\end{tabular}


Araştırmaya katılanlardan organik gida tanımlaması değerlendirildiğinde; okuryazar olmayan bireylerin $\% 12.8$ 'i hormonsuz yetişmiş ürün, ilkokul eğitim seviyesindeki katılımcıların \%32.7'si doğal ürün ve \%31.9'u çevre dostu ürün, ortaokul eğitim seviyesindeki katılımcıların \%36.7'si tarım bakanlığı sertifikalı ürün ve \%30.4'ü sağlıklı gıda ürünü, lise eğitim seviyesindeki katılımcılar \%29'u çevre dostu ürün ve lisans seviyesindeki katılımcıların \%25'i ise diğer cevabını vermiştir.

Araştırmaya katılan bireylerin organik gıdayı tüketme nedenleri okuryazarlık durumu ile analiz edildiğinde; lisans eğitim seviyesinde olan katılımcıların \%55.1'i organik gidanın kalitesine güvendikleri ve $\% 48.1$ 'i besin değeri yüksek olduğu için, ilkokul eğitim seviyesindeki katılımcıların \%44.4'ü ise fiyatının uygun olduğunu düşündükleri için organik gıdayı tercih ettiğini ifade etmişlerdir (Tablo 3).

Araştırmaya katılanların organik gıda satın alırken en çok tercih ettikleri ürünler ile okuryazarlık durumu değerlendirildiğinde; okuryazar olmayan bireylerin \%11.7'si tahıl ürünleri, ilkokul eğitimindeki katılımcıların \%21.4'ü tahıl ile et ürünleri, ortaokul eğitimine sahip katılımcılar $\% 14.6$ 's1 tahıl ürünleri, lise eğitimdeki katılımcıların \%14.2'si süt, \%17.1'i et ürünleri ve lisans seviyesindeki katılımcıların \%52.8'i süt, $\% 51.4$ 'ü ise et ürünleri tercih ettikleri anket sonucu tespit edilmiştir (Tablo 4).

Tablo 4. Okuryazarlık durumuna göre "Organik Gıda" hakkında yeterli bilgiye sahip olmayan katılımcıların cevaplarının analizleri

\begin{tabular}{|c|c|c|c|c|c|c|c|c|c|c|c|}
\hline & \multicolumn{10}{|c|}{ Eğitim } & \multirow{3}{*}{$\begin{array}{c}\chi^{2} \\
\mathrm{p}\end{array}$} \\
\hline & \multicolumn{2}{|c|}{$\begin{array}{l}\text { Okuryazar } \\
\text { değil }\end{array}$} & \multicolumn{2}{|c|}{ İlkokul } & \multicolumn{2}{|c|}{ Ortaokul } & \multicolumn{2}{|c|}{ Lise } & \multicolumn{2}{|c|}{ Lisans } & \\
\hline & $\mathrm{n}$ & $\%$ & $\mathrm{n}$ & $\%$ & $\mathrm{n}$ & $\%$ & $\mathrm{n}$ & $\%$ & $\mathrm{n}$ & $\%$ & \\
\hline \multicolumn{12}{|l|}{ Organik gıdaları tüketmemenizin en önemli sebebi nedir? } \\
\hline Pahalı & 6 & 33.3 & 10 & 41.7 & 10 & 37.0 & 20 & 57.1 & 43 & 50.6 & \multirow{5}{*}{$\begin{array}{l}28.02 \\
0.03\end{array}$} \\
\hline Alışveriş yaptığım yerde bulunmuyor & 0 & 0.0 & 2 & 8.3 & 3 & 11.1 & 7 & 20.0 & 20 & 23.5 & \\
\hline Organik ürünleri diğer ürünlerden farklı göremiyorum & 5 & 27.8 & 6 & 25.0 & 7 & 25.9 & 1 & 2.9 & 6 & 7.1 & \\
\hline Taze değil & 0 & 0.0 & 0 & 0.0 & 0 & 0.0 & 0 & 0.0 & 1 & 1.2 & \\
\hline Güvenli gelmiyor & 7 & 38.9 & 6 & 25.0 & 7 & 25.9 & 7 & 20.2 & 15 & 17.6 & \\
\hline \multicolumn{12}{|l|}{ Organik tarım logosunun ne anlama geldiğini biliyor musunuz? } \\
\hline Evet & 0 & 0.0 & 0 & 0.0 & 2 & 7.4 & 2 & 5.7 & 5 & 5.9 & \multirow[b]{2}{*}{$\begin{array}{l}2.822 \\
0.588\end{array}$} \\
\hline Hayır & 18 & 100.0 & 24 & 100 & 25 & 92.6 & 33 & 94.3 & 80 & 94.1 & \\
\hline \multicolumn{12}{|l|}{ Organik gıdaya ihtiyaç konusunda ne düşünüyorsunuz? } \\
\hline Çok ihtiyaç var & 13 & 72.2 & 16 & 66.7 & 22 & 81.5 & 21 & 60.0 & 72 & 84.7 & \multirow{4}{*}{$\begin{array}{l}19.32 \\
0.081\end{array}$} \\
\hline Biraz ihtiyaç var & 5 & 27.8 & 7 & 29.2 & 5 & 18.5 & 10 & 28.6 & 12 & 14.1 & \\
\hline Hemen hemen hiç yok & 0 & 0.0 & 0 & 0.0 & 0 & 0.0 & 2 & 5.7 & 0 & 0.0 & \\
\hline Hiç ihtiyaç yok & 0 & 0.0 & 1 & 4.2 & 0 & 0.0 & 2 & 5.7 & 1 & 1.2 & \\
\hline \multicolumn{12}{|c|}{ Organik gıda olarak satılan herhangi bir üründe ne gibi bir özellik olsaydı sizin o ürünü satın almanızı sağlardı? } \\
\hline Kesinlikle fiyatının uygun olması & 6 & 33.3 & 12 & 50.0 & 10 & 37.0 & 16 & 45.7 & 37 & 43.5 & \multirow{4}{*}{$\begin{array}{l}26.37 \\
0.009\end{array}$} \\
\hline Her yerde bulabileceğim bir ürün olmalı & 4 & 22.2 & 3 & 12.5 & 3 & 11.1 & 10 & 28.6 & 27 & 31.8 & \\
\hline Sertifikasının olduğunu bilmek & 1 & 5.6 & 4 & 16.7 & 8 & 29.6 & 7 & 20.0 & 16 & 18.8 & \\
\hline Diğer & 7 & 38.9 & 5 & 20.8 & 6 & 22.2 & 2 & 5.7 & 5 & 5.9 & \\
\hline \multicolumn{12}{|c|}{ Aşağıdakilerden hangisi organik gıda tüketiminizi arttırıcı bir sebep olabilir? } \\
\hline $\begin{array}{l}\text { Genetiğiyle oynanmamış, tohum kullanılarak elde edilmiş } \\
\text { temiz bir ürün olması }\end{array}$ & 6 & 33.3 & 4 & 16.7 & 3 & 11.1 & 14 & 40.0 & 33 & 38.8 & \multirow{4}{*}{$\begin{array}{l}29.66 \\
0.003\end{array}$} \\
\hline Gelecek nesilleri koruması & 2 & 11.1 & 1 & 4.2 & 6 & 22.2 & 8 & 22.9 & 7 & 8.2 & \\
\hline $\begin{array}{l}\text { Yapay kimyasalların insanlar, çevre ve hayvanlar üzerine } \\
\text { olumsuz etkilerini önleyerek toprak, hava ve su kalitesini } \\
\text { korumasi }\end{array}$ & 4 & 22.2 & 5 & 20.8 & 11 & 40.7 & 7 & 20.0 & 27 & 31.8 & \\
\hline Daha güvenli ve daha uygun maliyetli satılan bir ürün olması & 6 & 33.3 & 14 & 58.3 & 7 & 25.9 & 6 & 17.1 & 18 & 21.2 & \\
\hline
\end{tabular}

Araştırmadaki kişilerin organik gıda tüketmelerinin en önemli sebepleri ile eğitim durumları arasında anlamlı bir farklılık vardır $(\mathrm{p}<0.05)$. Eğitim durumuna göre değerlendirilen katılımcılar organik gıda tercih etmemelerinin nedeni olarak ankette "organik gıdaların güvenli gelmediği”" seçeneğini işaretlemiştir.
Araştırmada kişilerin organik gıda logosunun ne anlama geldiğini bilip bilmemeleri durumu ile eğitim durumları arasında anlamlı bir farklılık yoktur $(\mathrm{p}>0.05)$. Her eğitim grubundan katılımcı "organik gida logosunun ne anlama geldiğini bilmiyorum" seçeneğini işaretlemiştir. Araştırmada kişilerin 
organik gıdaya ihtiyaç konusundaki yaklaşımları ile eğitim durumları arasında anlamlı bir farklılık yoktur $(\mathrm{p}>0.05)$. Her eğitim grubundan katılımeı "organik gıdaya çok ihtiyaç var" seçeneğini işaretlemiştir. Araştırmada kişilerin organik gıda olarak satılan herhangi bir üründe ne gibi bir özellik olsaydı sizin o ürünü satın almanızı sağlardı yaklaşımları ile eğitim durumları arasında istatistiksel olarak anlamlı bir farklılık bulunmuştur $(\mathrm{p}<0.05)$. Okuryazar olmayan katılımcılar ankette diğer nedenler seçeneğini işaretlerken; ilkokul, ortaokul, lise ve lisans eğitim seviyesindeki katılımcılar ankette "ürün fiyatının uygun olması" seçeneğini işaretlemiştir.

Araştırmada kişilerin organik gıda tüketimini arttırıcı sebepler ile eğitim durumları arasında istatistiksel olarak anlamlı bir farklılı vardır $(\mathrm{p}<0.05)$. Okuryazar olmayan katılımcılar, genetiğiyle oynanmamış, tohum kullanılarak elde edilmiş temiz bir ürün olması, daha güvenli ve daha uygun maliyetli satılan bir ürün olması durumunda, ilkokul eğitim seviyesindeki katılımcılar daha güvenli ve daha uygun maliyetli satılan bir ürün olması durumunda, ortaokul seviyesindeki katılımcılar yapay kimyasalların insanlar, çevre ve hayvanlar üzerine olumsuz etkilerini önleyerek toprak, hava ve su kalitesini koruması durumunda, lise eğitim seviyesindeki katılımcılar genetiğiyle oynanmamış, tohum kullanılarak elde edilmiş temiz bir ürün olması durumunda ve lisans eğitim seviyesindeki katılımcılar ise genetiğiyle oynanmamış, tohum kullanılarak elde edilmiş temiz bir ürün olması durumunda ve yapay kimyasalların insanlar, çevre ve hayvanlar üzerinde olumsuz etkilerini önleyerek toprak, hava ve su kalitesini koruması durumlarında organik gida tüketiminin artacağını belirten seçeneği işaretlemiştir.

\section{TARTIŞMA}

Organik gıda tüketiminin sağlık motivasyonları üzerinde önemli bir gücü olmasına rağmen, organik ürünlerin organik olmayanlara göre daha sağlıklı olduklarını bilimsel olarak kanıtlamak zor gibi görünüyor. ${ }^{24,25}$ Sağlık bilinci, kişileri sağlıkla ilgili alınacak her türlü karar konusunda gönüllü kılmaktadır. $\mathrm{Bu}$ kişiler genelde; nasıl bir yaşam sürerlerse, nasıl aktivitelerde bulunurlarsa ne yiyip ne içerlerse daha sağlıklı olacaklarını araştırırlar, bu sorulara cevap bulmak için uğraşırlar, okurlar ve bu kişilerin dış uyarıcılara karşı algıları çok açıktır. Literatürde organik ürünlerin tercih edilme sebepleri incelendiğinde ilk sırada sağlıkla ilgili faydaları yer almaktadır. ${ }^{26-30}$ Yapılan çalışmalara paralel olarak bu çalışmada da katılımcıların çoğunluğunun organik gıdaları sağlıklı buldukları saptanmıştır. Çalışmalarda ise organik ürünlerin pahalı olması ve sayıca yetersizliği organik ürün tüketimini sınırlayan unsurlar olarak belirlenmiştir. ${ }^{31,32}$ Organik ürünler ile geleneksel ürünleri satın alan tüketicileri Lea ve Worsley $^{33}$ Avustralya ekseninde karşılaştırmaya çalışmıştır. Araştırmada, organik ürünlerin geleneksel ürünlere göre daha lezzetli, sağlıklı ve çevreye duyarlı olduğu sonucuna ulaşılmıştır. $\mathrm{Bu}$ çalışmada tüketicilerin organik gıdalara karşı bakış açıları değerlendirilirken, organik gida tercih etme nedenlerinin başında besin değerinin yüksek olması, kalitesinin güvenilir olması, doğal yaşama katkı sağlaması, tat ve lezzetinin iyi olması gelmektedir. Ayrıca gelir düzeyi düşük veya yüksek olan bireylerin organik gıdaları pahalı buldukları tespit edilmiştir. Çalışmada kişilerin organik gida olarak satılan herhangi bir üründe ne gibi bir özellik olsaydı sizin o ürünü satın almanızı sağlardı yaklaşımları ile eğitim durumları arasında anlamlı bir farklılık bulunmuştur. Okuryazar olmayan katılımcıların belirttikleri diğer sebepler dolayısıyla ürünü satın alabileceklerini söylerken, ilkokul, ortaokul, lise ve lisans eğitimi seviyesindeki katılımcılar ürünün fiyatı uygun olursa kesinlikle ürünü alabileceklerini ifade etmişlerdir. $\mathrm{Bu}$ bulgunun sonucu okuryazar olmayan bireylerin organik gıdalarla ilgili daha çok sorguladıklarını göstermektedir (kalitesi, çeşitliliği, üretim koşulları vb.).

Ülkemizde 2013 yılında yapılmış bir çalışmada da organik gida satın alarak modaya uymak ile organik gıdaları merak etmekten ötürü satın almak arasında pozitif doğrusal bir ilişkiye rastlanmıştır. ${ }^{34} \mathrm{Bu}$ durum bireylerin organik gida hakkında yeterli ve doğru bilgiye sahip olmadan tüketimlerine zemin hazırlamaktadır.

\section{SONUÇ}

Çalışmada her eğitim grubundan katılımcı, organik gida logosunun ne anlama geldiğini bilmemektedir. Organik tarım logosunu bilmeyen kişilerin çoğu ise üniversite düzeyinde eğitimli kişilerdir. $\mathrm{Bu}$ durum tüketicilerin yeterli bilgiye sahip olmadan organik gıdaları farklı değerlendirerek bireyleri yanlış tüketime itmektedir. Dolayısıyla bu ve bunun gibi çelişkili çalışmalar organik gıda konusunda tüketiciyi etkilemektedir. Sağlıklı ve güvenli gıda maddelerine olan talebin gelecek y1llarda daha da artması beklenmektedir. Yukarıdaki öneriler doğrultusunda tüketicilerin organik gıdalara bakış açıları değerlendirilirken bireylerin daha fazla bilgilendirilmeye, farkındalık kazandırmaya ve yönlendirilmeye ihtiyaç vardır. Satın alınacak gıdaların tercihi konusundaki bilgilenmenin, tüketici bilinci doğrultusunda yeni metotlarla desteklenmesi gerekmektedir. Bunlara ek olarak doğa ve insan sağlığı korunacak, gelecek nesillere iyi bir dünya bırakabilecektir. Sonuç olarak bu konunun daha çok araştırmaya ihtiyaç vardır.

\section{KAYNAKLAR}

1. Annunziata A, Vecchio R. Organic farming and sustainability in food choices: an analysis of consumer preference in Southern Italy. 
Agriculture and Agricultural Science Procedia. 2016;8:193-200.

2. Alnıaçı Ü, Koç F. Yeni Çevresel Paradigma Ölçeği ile üniversite öğrencilerinin çevreye yönelik tutumlarının değerlendirilmesi. Balıkesir Üniversitesi Burhaniye MYO Bölgesel Kalkınma Kongresi, 14-16 Kasım 2009, Balıkesir.

3. Yücel M, Altunkasa F, Güçray SS, Uslu C, Peker Say N. Adana'da halkın çevre duyarlılığının saptanması ve bu duyarlılığ arttırabilecek önlemlerin geliştirilmesi. Çukurova Üniversitesi Bilimsel Araştırma Projeleri, Proje No: ZF2004BAP12, 2006, Adana.

4. Aksoy U, Altındişli A. Ekoloji (Organik, Biyolojik) Tarım Organizasyonu Derneği, 1998, İzmir.

5. Ataseven Y. Tarımsal faaliyetlerin içme suyu havzalarındaki etkilerinin araștırılması: Ankara ili örneği. Ankara Üniversitesi Tarım Ekonomisi Anabilim Dalı Doktora Tezi, 2010, Ankara.

6. Dabbert S, Haring AM, Zanoli R. AB ve Türkiye'de Organik Tarım, çev. Harun Vatansever, Özkan Matbaacılık, Ankara, 2007:3.

7. FIBL \& IFOAM- Organics international: the world of organic agriculture statistic and emerging trends, 2016.

8. Vatansever Deviren N, Çelik İlal N. Dünya'da ve Türkiye'de organik tarımın ekonomik açıdan değerlendirilmesi. Uluslararast Sosyal Araştırmalar Dergisi. 2017;10(48):669-678.

9. Chen M.F. Consumer attitudes and purchase intentionsin relation to organic foods in Taiwan: Moderating effects of food-related personality traits. Food Quality and Preference. 2007;18(7):1008-1021.

10. Lockie S, Lyons K, Lawrence G, Mummery K. Eating green: motivations behind organic food consumption in Australia. European Society for Rural Sociology. 2002;41(1):23-40.

11. Chinnici G, D'Amico M, Pecorino B. A multivariate statistical analysis on the consumers of organic products. British Food Journal. 2002;104(3):17-23.

12. United States Department of Agriculture (USDA). Organic labeling and marketing information National Organic Program, Policy No. 202-720-3252, 2008. Retrieved from www.ams.usda.gov/nop.

13. Organic Myths.http://www.organic.org/articles /showarticle/article-207. Erişim Tarihi: 19.04.2011

14. Koç Subaşı D. Organik Tarım Ürünleri Dış Pazar Araştırması, Dış Ticaret Müsteşarlığ 1 İhracatı Geliștirme Etüt Merkezi, 2009, Ankara.

15. Uesangkomsate P, Santiteerakul S. A study of consumers' attitudes and intention to buy organic foodsfor sustainability. Procedia Environmental Sciences. 2016;(34), 423-430.

16. Ottman J, Books NB. Green marketing: Opportunity for innovation. The Journal of Sustainable Product Design. 1998;60(7):136667.
17. Mishar P, Sharma P. Green marketing in India: Emerging opportunities and challenges. Journal of Engineering Science and Management Education. 2010;3(1):9-14.

18. Jones P, Hill CC, Hiller D. Case study: retailing organic food products. British Food Journal. 2001;103(5):358-365.

19. Yu X, Gao Z, Zeng Y. Willingness to pay for the "Green Food" in China. Food Policy. 2014;45:80-87.

20. Rezai G, Teng PK, Mohamed Z, Shamsudin MN. Consumer' awareness and consumption intention towards green foods. African Journal of Business Management. 2012;6(12):44964503.

21. Schifferstein HNJ, Oude Ophuis PAM. Healthrelated determinants of organic food consumption in the Netherlands. Food Quality and Preference. 1998;9(3):119-133.

22. Magnusson M, Arvola A, Koivisto U, Aberj L, Sjoden P. Attitudes towards organic foods among Swedish consumers. British Food Journal. 2001;103:209-226.

23. Magkos F, Arvaniti F, Zampelas A. Organic food: buying more safety or just peace of mind? A critical review of the literature. Critical Reviews in Food Science and Nutrition. 2006;46:23-56.

24. Taro Y. Temel Örnekleme Yöntemleri. 3. Basım, İstanbul: Literatür yayıncılık; 2010.

25. Kalaycı Ş. Çok Değişkenli İstatistik Teknikleri. Ankara: Dinamik Akademi; 2018.

26. Lund TB, Jensen KO. Consumption of organic foods from a life history perspective: An explorative study among Danish consumers. Country Report Denmark, Department of Human Nutrition, University of Copenhagen Denmark, 2008.

27. Guéguen L, Pascal G. Organic foods. In: Encyclopedia of Human Nutrition, ed. Caballero B. 3rd ed. UK: Elsevier;2013:413417.

28. Shaharudin MR, Pani, JJ, Mansor SW, Elias SJ, Sadek DM. Purchase intention of organic food in Malaysia: a religious overview. International Journal of Marketing Studies. 2010;2(1):96.

29. Özçelik A, Uçar A. Turkish academic staffs' perception of organic foods. British Food Journal. 2008;110(9):948-960.

30. Lodorfos G, Dennis J. Consumers' intent: in the organic food market. Journal of Food Product Marketing. 2008;14(2):17-38.

31. Padel S, Foster C. Exploring the gap between attitudes and behaviour: Understanding why consumers buy or do not buy organic food. British Food Journal. 2005;107(8):606-625.

32. Wier M, Calverley C. Market potential for organic foods in Europe. British Food Journal. 2002;104(1):45-62.

33. Lea E, Worsley T. Australians' organic food beliefs, demographics and values. British Food Journal. 2005;107:855-869.

34. Çelik S. Kimler, neden organik gida satın alıyor? Bir alan araştırması. Selçuk Üniversitesi Sosyal Bilimler Enstitüsü Dergisi. 2013:(30):93-108. 